\title{
Iron metabolism and its contribution to cancer (Review)
}

\author{
YING CHEN $^{1,2^{*}}$, ZHIMIN FAN $^{1 *}$, YE YANG $^{2,3}$ and CHUNYAN GU ${ }^{1,2}$ \\ ${ }^{1}$ National Medical Centre of Colorectal Disease, The Third Affiliated Hospital, Nanjing University of Chinese Medicine, \\ Nanjing, Jiangsu 210001; ${ }^{2}$ School of Medicine and Life Sciences; ${ }^{3}$ School of Holistic Integrative Medicine, \\ Nanjing University of Chinese Medicine, Nanjing, Jiangsu 210023, P.R. China
}

Received October 2, 2018; Accepted January 21, 2019

DOI: $10.3892 /$ ijo.2019.4720

\begin{abstract}
Iron is an essential element for biological processes. Iron homeostasis is regulated through several mechanisms, from absorption by enterocytes to recycling by macrophages and storage in hepatocytes. Iron has dual properties, which may facilitate tumor growth or cell death. Cancer cells exhibit an increased dependence on iron compared with normal cells. Macrophages potentially deliver iron to cancer cells, resulting in tumor promotion. Mitochondria utilize cellular iron to synthesize cofactors, including heme and iron sulfur clusters. The latter is composed of essential enzymes involved in DNA synthesis and repair, oxidation-reduction reactions, and other cellular processes. However, highly increased iron concentrations result in cell death through membrane lipid peroxidation, termed ferroptosis. Ferroptosis, an emerging pathway for cancer treatment, is similar to pyroptosis, apoptosis and necroptosis. In the present review, previous studies on the physiology of iron metabolism and its role in cancer are summarized. Additionally, the significance of iron regulation, and the association between iron homeostasis and carcinogenic mechanisms are discussed.
\end{abstract}

\section{Contents}

1. Introduction

2. Iron absorption

3. Iron distribution and excretion

4. Iron and various cancers

5. Mechanisms of iron-mediated proliferation of tumor cells

6. Ferroptosis: Iron-dependent cancer cell death

7. Conclusions

Correspondence to: Professor Chunyan Gu or Professor Ye Yang, School of Medicine and Life Sciences, Nanjing University of Chinese Medicine, 138 Xinlin Road, Nanjing, Jiangsu 210023, P.R. China

E-mail: guchunyan@njucm.edu.cn

E-mail: yangye876@sina.com

*Contributed equally

Key words: iron, absorption, excretion, cancer, ferroptosis, mitochondria

\section{Introduction}

As a fundamental inorganic nutrient in the human body, iron serves an important role in numerous biological processes, including DNA and RNA synthesis, oxygen transport, cellular respiration, the activity of numerous enzymes, heme synthesis, detoxification processes, and immune function and metabolism (1). Iron homeostasis is tightly regulated in healthy cells by balancing absorption, systemic transportation, and cellular uptake and storage (2). However, dysregulation of this balance may increase the risk of cancer and has been associated with carcinogenesis $(3,4)$. Numerous studies have investigated iron regulation pathways and examined the association between increases in iron concentration and enhanced tumor growth (5-7). For instance, high-iron clusters were observed in macrophage deposits in mammary tumors, lung metastases and brain metastases with the accumulation of hemosiderin (8).

Iron is an indispensable element for the synthesis of iron sulfur clusters, which are versatile and used by enzymes for vital cellular processes in normal and cancer cells (9). However, a high concentration of oxygen makes iron sulfur clusters susceptible to oxidation and Fenton reactions resulting in DNA damage $(10,11)$. Increasing intracellular labile iron pools, using iron sucrose, may be applied to enhance the toxicity of pharmacological ascorbate in human colon cancer cells by increasing the generation of $\mathrm{H}_{2} \mathrm{O}_{2}$ (12). Additionally, iron excess in tumor cells, due to an excessive dietary intake and/or genetic factors, makes iron deprivation a principal strategy of chemotherapy for multiple types of human cancer $(13,14)$. However, despite great progress, the association between iron metabolism and cancer has yet to be fully elucidated. The present review summarizes recent studies on novel processes and mechanisms of iron transport into cells, which could promote cancer cellular proliferation. The concepts discussed in the present study may provide a novel approach to cancer prognosis and therapy.

\section{Iron absorption}

Iron is not synthesized during physiological processes. Therefore, iron concentrations must be maintained through nutrition. Iron from food is primarily absorbed by duodenum enterocytes (90\%). The stomach does not contribute much in the assimilation of iron, as its absorption is $\leq 2 \%$ of the total intake (15). There are two types of dietary iron that may be 
absorbed: Heme iron, from the breakdown of hemoglobin and myoglobin in red meat, or non-heme inorganic iron, which is predominantly released from foods, including vegetables and cereals $(16,17)$.

Dietary iron is present in the ferric form $\left(\mathrm{Fe}^{3+}\right)$. Prior to absorption, $\mathrm{Fe}^{3+}$ is reduced to ferrous iron $\left(\mathrm{Fe}^{2+}\right)$ by duodenal cytochrome b (Dcytb), a brush border membrane ferrireductase (Table I). $\mathrm{Fe}^{2+}$ is subsequently transported across the apical membrane of enterocytes through divalent metal transporter 1 (DMT1; Table I). Hemoglobin and myoglobin are more bioavailable compared with inorganic iron (18). Researchers studied young iron-deficient piglets to investigate the pathways of heme iron absorption and to determine the efficacy of oral heme iron supplementation (16). The stomach and duodenum degrade hemoglobin to heme prior to absorption by the proximal part of the duodenum. Intact heme is transported to the enterocyte interior via heme carrier protein 1 and heme responsive gene-1 (HRG1) importers. There are two separate pathways involved in the absorption of heme iron. The first pathway involves heme oxygenase-1 (HO-1) catabolizing intracytoplasmic heme into ferrous ion, which follows the fate of inorganic dietary iron ions. The second pathway involves heme iron being transported across the basolateral membrane by feline leukemia virus subgroup $C$ cellular receptor 1 and captured by hemopexin in plasma to form a heme-hemopexin complex (Hpx-heme). Subsequently, Hpx-heme is transported into various sites in the body via prolow-density lipoprotein receptor-related protein 1 (19).

In the cytosol, iron is neutralized by ferritin (a multimeric iron-storage protein) (Table I) and weakly bound together to form a pool of iron termed the cytoplasmic labile iron pool (cLIP) (20). The cLIP supplies iron to a number of cytoplasmic enzymes, in addition to mitochondria for heme and iron sulfur cluster synthesis. Ferroportin (FPN) (Table I), the iron transporter at the basolateral membrane of intestinal enterocytes, is the principal cellular iron exporter and transfers duodenal iron out of cells into circulation; this is the principal way for iron to enter systemic circulation (21). The released iron is reduced to ferrous ions by membrane-bound hephaestin or caeruloplasmin in plasma. These enzymes oxidize $\mathrm{Fe}^{2+}$ to $\mathrm{Fe}^{3+}$ and load $\mathrm{Fe}^{3+}$ onto transferrin (Tf) in the blood (22). Subsequently, Tf combines with the transferrin receptor (TfR) on cytomembranes. Hepcidin (Hep), a protein secreted by hepatocytes, binds to FPN, ceasing cellular iron export (Table I) (23-32).

Ferric ions are reduced by Dcytb and subsequently enter enterocyte epithelial cells via DMT1. Some of the iron is stored in ferritin and some passes through FPN into the plasma. In specific cases, Hep may prevent FPN from releasing the iron. Tf takes the released iron to TfR on the cell surface, the ion is then used by the cells. Other specific proteins are involved in iron intake, including zinc transporter (ZIP)14, ZIP8, transient receptor potential cation channel 6 (TRPC6), L-type calcium channels (LTCCs) and T-type calcium channels (TTCCs; Fig. 1).

Dcytb. As a member of the cytochrome b561 family, Dcytb serves a vital role in the ascorbate-dependent reduction of inorganic iron in duodenal enterocytes. Besides Dcytb, there are additional members of the cytochrome b561 family, including stromal cell-derived receptor 2, cytochrome b ascorbate-dependent protein 3 and cytochrome b561 domain-containing protein $2(33,34)$. Dcytb reduces extracellular ferric iron to ferrous ion $(24,35)$. The expression of Dcytb may be modulated by the iron regulatory protein 1-hypoxia-inducible factor $2 \alpha$ axis $(24,36)$.

DMT1. DMT1 is well known for its involvement in ferric iron influx into the duodenum cytoplasm. In erythroid precursors, hepatocytes and macrophages, DMT1 is the principal contributor in iron transport, transporting iron out of the endosome and into the cytosol (37). DMT1 is also expressed in other tissues, including the kidneys, liver, brain and heart (25). When animals exhibit iron deficiency, the expression of DMT1 is increased in the duodenum to elevate iron absorption (38). This process is regulated by an iron responsive element (IRE) at the 3'-untranslated region of DMT1 $(37,39)$.

Ferritin. Ferritin forms a hollow shell that may bind $\leq 4,500$ atoms of iron. Ferritin consists of 24 subunits, and has a combination of a heavy $(\mathrm{H})$ chain and light $(\mathrm{L})$ chain ferritin types (40). H-type ferritin ferroxidase quickly oxidizes iron to $\mathrm{Fe}^{3+}$ following $\mathrm{Fe}^{2+}$ incorporation into ferritin, whereas, L-type ferritin may be responsible for the electron transfer across the globular protein cage (41). Since free iron is toxic inside the cells, ferritin stores excess iron and is ligated in labile cellular iron to protect cells from iron toxicity. Ferritin stores are subsequently exported as ferrous ions to the plasma via FPN, or utilized when cells are subjected to iron deficiency. Ferritin is not only detected intracellularly, it is also located extracellularly in the serum, cerebrospinal fluid and synovial fluid. Serum ferritin is associated with inflammation and body iron load in patient populations (42). The expression of ferritin may be modulated by the iron regulatory protein 1 (IRP)-IRE system at the post-transcriptional level.

FPN. FPN, encoded by SLC40A1 (additionally termed SLC11A3, MTP1 or IREG1), is the only known cellular iron exporter in mammals and is highly expressed in spleen macrophages, the liver, and the basolateral membranes of enterocytes and erythroid precursors $(43,44)$. Macrophages, liver cells and enterocytes export $\mathrm{Fe}^{2+}$ to the blood via FPN. Subsequently, hephaestin or ceruloplasmin oxidizes $\mathrm{Fe}^{2+}$ to $\mathrm{Fe}^{3+}$ in order to bind Tf. FPN may be inhibited by Hep binding to cell surface-localized FPN (Fig. 1A), which leads to FPN internalization and degradation, and consequently to the loss of iron export capacity (45).

Tfand TfR. Tf is the primary extracellular iron transport protein in blood. Tf possesses a single chain bilobal protein. Each lobe has a high affinity for $\mathrm{Fe}^{3+}(45)$. The combination of $\mathrm{Tf}-\mathrm{Fe}^{3+}$ is reversible, thus making it a convenient method to deliver iron to cells. Tf has two conformations: Apo Tf (the iron-free form of Tf) and holo Tf (the iron-saturated form), of which the latter buries iron deeply within each lobe (46). Tf is secreted by the liver and under normal circumstances $20-30 \%$ of $\mathrm{Tf}$ is bound to iron. If circulating iron levels exceed the binding capacity of Tf, toxic non-Tf-bound iron may accumulate, leading to various diseases (47). TfR mediates cellular iron uptake by binding and internalizing Tf. TfR expression is tightly regulated by iron levels in the cLIP inside cells. 
Table I. The characteristics of protein associated with iron.

\begin{tabular}{|c|c|c|c|c|}
\hline Protein & $\begin{array}{l}\text { Human } \\
\text { chromosome }\end{array}$ & Location & $\begin{array}{l}\text { The content of iron } \\
\text { in cytoplasm }\end{array}$ & Refs. \\
\hline Dcytb & 2 & Duodenal enterocytes & $\mathrm{Fe}^{2+} \rightarrow \mathrm{Fe}^{3+}$ & (24) \\
\hline DMT1 & 12 & Enterocytes surface and endosome & $\mathrm{Fe}^{3+\uparrow}$ & $(25)$ \\
\hline Ferritin & H chain $11 \mathrm{~L}$ chain 19 & Cytoplasm & Store iron & $(26)$ \\
\hline Ferroportin & 2 & Cell membrane & $\mathrm{Fe}^{3+} \downarrow$ & $(27)$ \\
\hline Hepcidin & 19 & Plasma great secretion majority by liver & $\mathrm{Fe}^{3+\uparrow}$ & $(28)$ \\
\hline ZIP14 & 8 & Basolateral membrane & $\mathrm{Fe}^{2+} \uparrow$ & $(29)$ \\
\hline ZIP8 & 4 & Apical membrane & $\mathrm{Fe}^{2+\uparrow}$ & $(30)$ \\
\hline TRPC6 & 11 & Cell membrane & $\mathrm{Fe}^{2+}$ and $\mathrm{Fe}^{3+} \uparrow$ & $(31)$ \\
\hline LTCCs and TTCCs & $\begin{array}{c}1,3,12, X \text { and } \\
16,17,22\end{array}$ & Cell membrane & $\mathrm{Fe}^{2+} \uparrow$ & $(32)$ \\
\hline
\end{tabular}

H, heavy; L, light; Dcytb, duodenal cytochrome b; DMT1, divalent metal transporter 1; ZIP, zinc transporter; TRPC6, transient receptor potential cation channel 6; LTCCs, L-type calcium channels; TTCCs, T-type calcium channels.

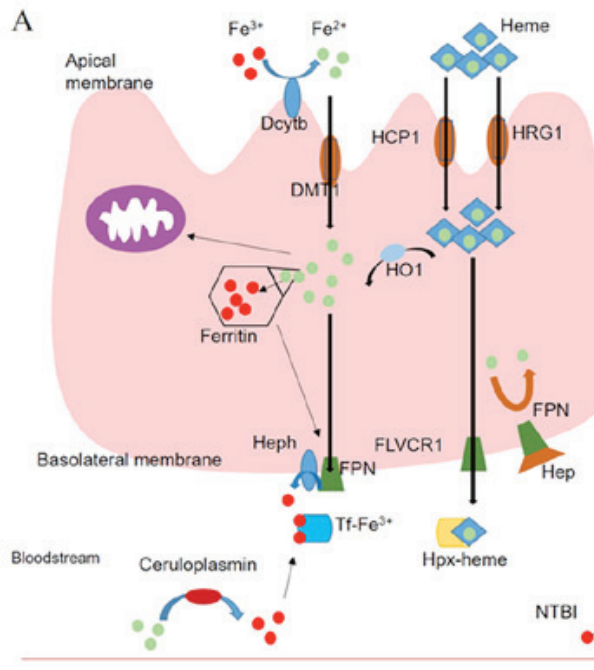

B
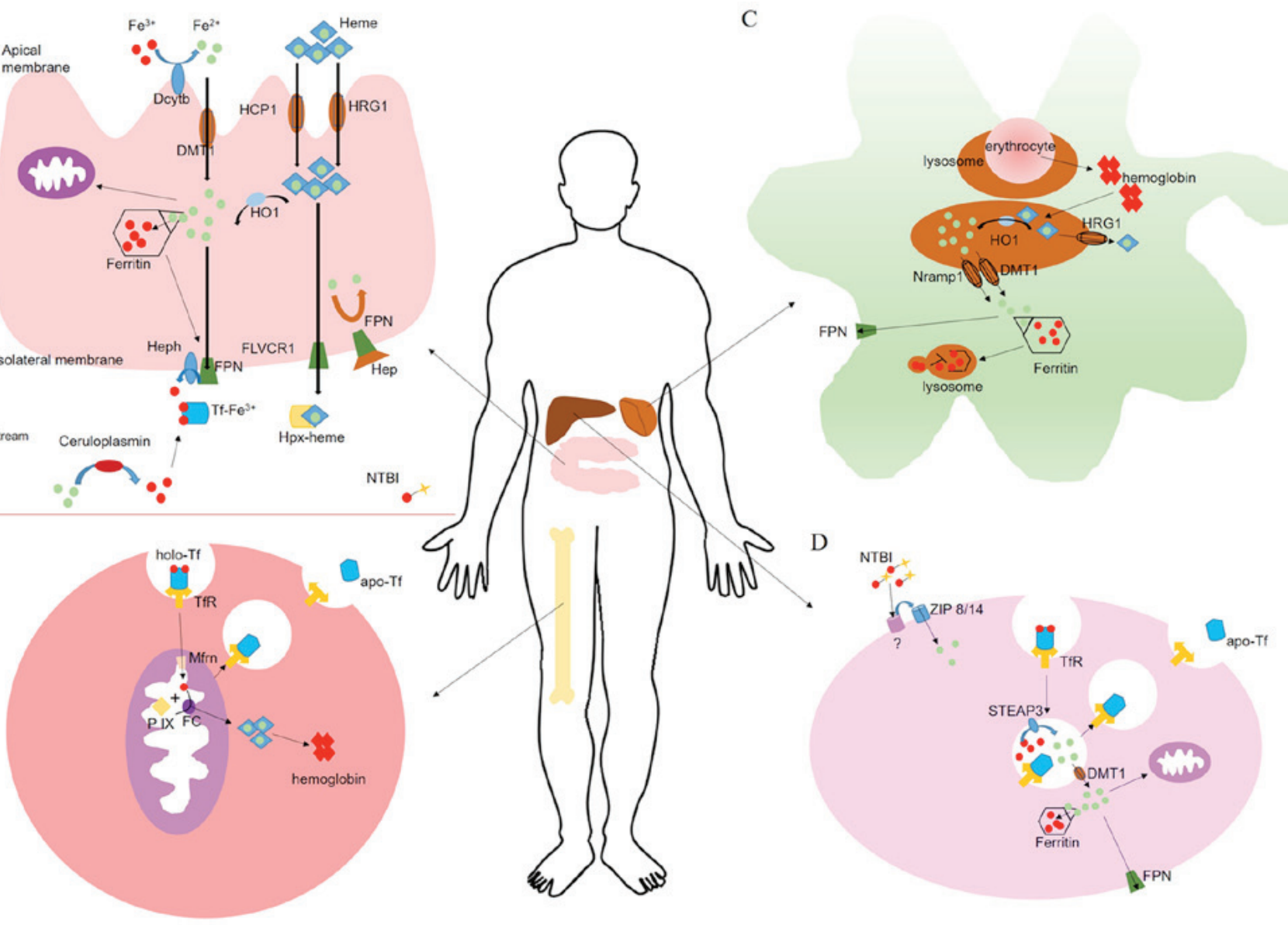

Figure 1. Overview of iron homeostasis in the human body. Iron homeostasis in a (A) duodenal enterocyte, (B) erythrocyte, (C) macrophage and (D) liver tissue cell.

Hep. Hep (also termed liver-expressed antimicrobial peptide 1) is a peptide comprising 25 amino acids encoded by $H A M P$, and is predominantly expressed in the liver, and to a lower extent, in the heart. Additionally, Hep may be secreted by macrophages, lymphocytes, adipocytes, pancreatic $\beta$-cells, neutrophils and renal cells (48). Hep regulates cellular iron export and regulates the iron concentration of plasma by binding to FPN, thus triggering the internalization and degradation of FPN (49). The storage of systemic iron is closely associated with the synthesis of Hep. When plasma iron is deficient, Hep transcription is decreased in the liver. As the plasma iron concentration increases, the Hep expression 
level increases. However, a high concentration of Hep in the blood negatively regulates iron absorption, and consequently, the release of iron into the plasma is decreased (50).

\section{Iron distribution and excretion}

Iron is transported in a cycle of Tf-bound and non-Tf-bound iron (NTBI) forms. In steady state conditions, iron is loaded onto Tf. Iron distribution is achieved using primary pathways: Iron utilization in erythropoiesis, erythrocyte recycling by macrophages and iron uptake into tissue (Fig. 1B-D). In total, $\sim 24 \mathrm{mg}$ of iron is utilized at erythropoiesis (the process that generates erythrocytes) per day. Macrophages phagocytose aged erythrocytes to recycle iron (51). For humans, there is no biological mechanism for the excretion of iron. Healthy adults lose $\sim 5 \%$ of plasma iron through gastro-intestinal tract lining desquamation, skin or blood loss $(37,52)$.

Iron and erythropoiesis. Erythropoiesis is characterized by three progressive stages from progenitor cells to precursor cells and, ultimately, to mature RBCs in bone marrow (53). Erythroid progenitors (burst forming unit-erythroids and colony forming unit-erythroids) have the capacity to differentiate to proerythroblasts, basophilic erythroblasts, polychromatophilic erythroblasts, orthochromatic erythroblasts, reticulocytes and mature erythrocytes (53). Maturation and proliferation of early erythroid progenitor cells depends on erythropoietin, which is a cytokine produced by the kidneys (54).

The body produces $\sim 200$ billion erythrocytes every day. Erythropoiesis is the largest consumer of iron in the body (>80\% of plasma iron). Macrophages phagocytose senescent erythrocytes and release hemoglobin-derived iron into the blood. Hemoglobin-derived iron is the primary source of $\mathrm{RBC}$ regeneration. Erythrocytes contain hemoglobin, which are functionally responsible for transporting oxygen. Iron is the active site of hemoglobin binding oxygen. When heme synthesis and $\mathrm{Fe}-\mathrm{S}$ cluster biogenesis occur, the iron demand increases. To meet this demand, transferred iron is delivered to the mitochondrial matrix by mitoferrin and the insertion of $\mathrm{Fe}^{2+}$ into protoporphyrin IX is catalyzes to make heme by ferrochelatase, which is exported to the cytoplasm (Fig. 1B) (55).

Macrophage and erythrocytes. Iron homeostasis is regulated by circulating erythrocytes. Macrophages remove senescent erythrocytes through erythrophagocytosis (56). The majority of aged or damaged erythrocytes are removed to release iron for the production of novel RBCs. Red pulp splenic macrophages and the Kupffer cells (specialized macrophages) in liver sinusoids are primarily responsible for erythrophagocytosis. When the tissue microenvironment is triggered by iron instability, monocyte-derived macrophages are recruited to the liver, forming a liver-specific phenomenon (57).

Heme degradation is catalyzed by HO-1 in macrophage lysosomes. Prior to degradation, a part of heme is exported from the lysosome to the cytosol by HRG1. $\mathrm{Fe}^{2+}$ is exported from the lysosome to the cytoplasm by DMT1 and natural resistance-associated macrophage protein 1 (58). Subsequently, the iron is released into blood or accumulated by ferritin (Fig. 1C) (59).
Iron uptake into tissue. Iron is transported in the Tf cycle normally; however, iron additionally exists in the state of NTBI in iron loading conditions. TfR is expressed ubiquitously on the surface of the majority of cells and combines with holo $\mathrm{Tf}$ to form a complex, which is swallowed by the cells as an endosome. When the complex enters a cell, ferric ions are dissociated from $\mathrm{Tf}$ by acidification. At that time, apo-Tf remains bound to TfR; apo-Tf is released once the complex is transferred to the cell surface $(60,61)$. The ferrireductase protein, six-transmembrane epithelial antigen of prostate 3 (STEAP3), subsequently reduces $\mathrm{Fe}^{3+}$ to $\mathrm{Fe}^{2+}$ within the endosome. $\mathrm{Fe}^{2+}$ enters the cytoplasm of cells via DMT1.

The uptake of NTBI may be associated with ZIP8 and ZIP14 (Table I), which belong to the ZIP family of metal-ion transporters $(62,63)$. TRPC6, LTCCs and TTCCs (Table I) additionally serve a role in NTBI uptake. The ability of TRPC6 was first postulated in previous a study using PC12 cells (31). LTCCs and TTCCs are pore-forming voltage-gated calcium channels, and are associated with NTBI transport (64). Under NTBI circumstances, iron appears in plasma bound to acetate, citrate, albumin or other organic anions of intermediary metabolism (65). NTBI accumulation is a principal cause of iron toxicity in organs leading to oxidative stress and cellular damage (66). NTBI clearance is primarily performed by hepatocytes, which makes hepatocytes the first target of iron toxicity. However, other organs, including the hypophysis, pancreas or heart, are additionally influenced by NTBI uptake and accumulation (Fig. 1D) (51).

Redundant plasma iron, which is bound by ferritins, is stored in hepatocytes (54). High expression levels of FPN have been detected on cell surfaces (in particular, the highest expression was detected in cells of the periportal areas) that export large quantities of iron into the bloodstream (67). Spleen macrophages phagocytose erythrocytes to release iron from hemoglobin. In the pancreas, ferritin is segregated in lysosomes of acinar cells, and iron deposits are discrete and only in B cells (68). Iron is principally bound to Tf, whereas, a very small amount binds to other filterable iron-binding proteins, including neutrophil gelatinase-associated lipocalin, myoglobin, albumin, lactoferrin, hemoglobin and Hep (69). However, the mechanism of filtering iron by human kidney requires further investigation. In the distal and proximal tubules, iron is reabsorbed almost entirely. Resorbed iron may be utilized by mitochondrial proteins of the renal tubular epithelium or exported into blood or the interstitium via the basolateral membrane of tubular epithelial cells (70). Cardiomyocytes express relatively increased FPN and Hep; however, do not serve a role in systemic iron regulation (71).

\section{Iron and various cancers}

In 1959, an animal study first demonstrated that repeated intramuscular injections of iron dextran were able to induce malignant tumors (72). Over time, accumulating research demonstrated that the injection of iron preparations caused serious side effects, such as sarcomas, and exacerbated diseases $(73,74)$. Supersaturation ferric ion or iron exposure may increase cancer risk (75). Iron-status biomarkers are $\mathrm{Tf}$ saturation, the total iron binding capacity of $\mathrm{Tf}$ and the serum iron concentration, which are regulated by dietary iron intake, 

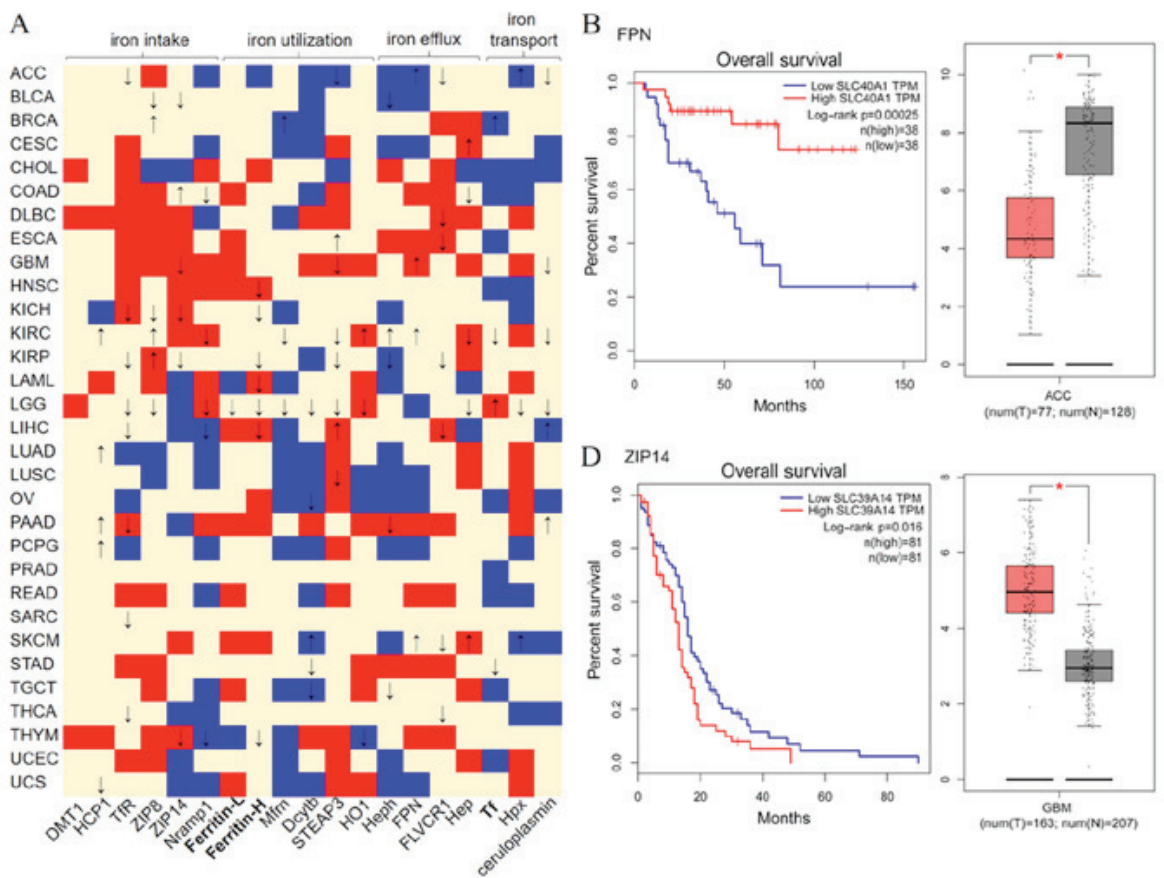

$\mathrm{C}_{\text {Hep }}$
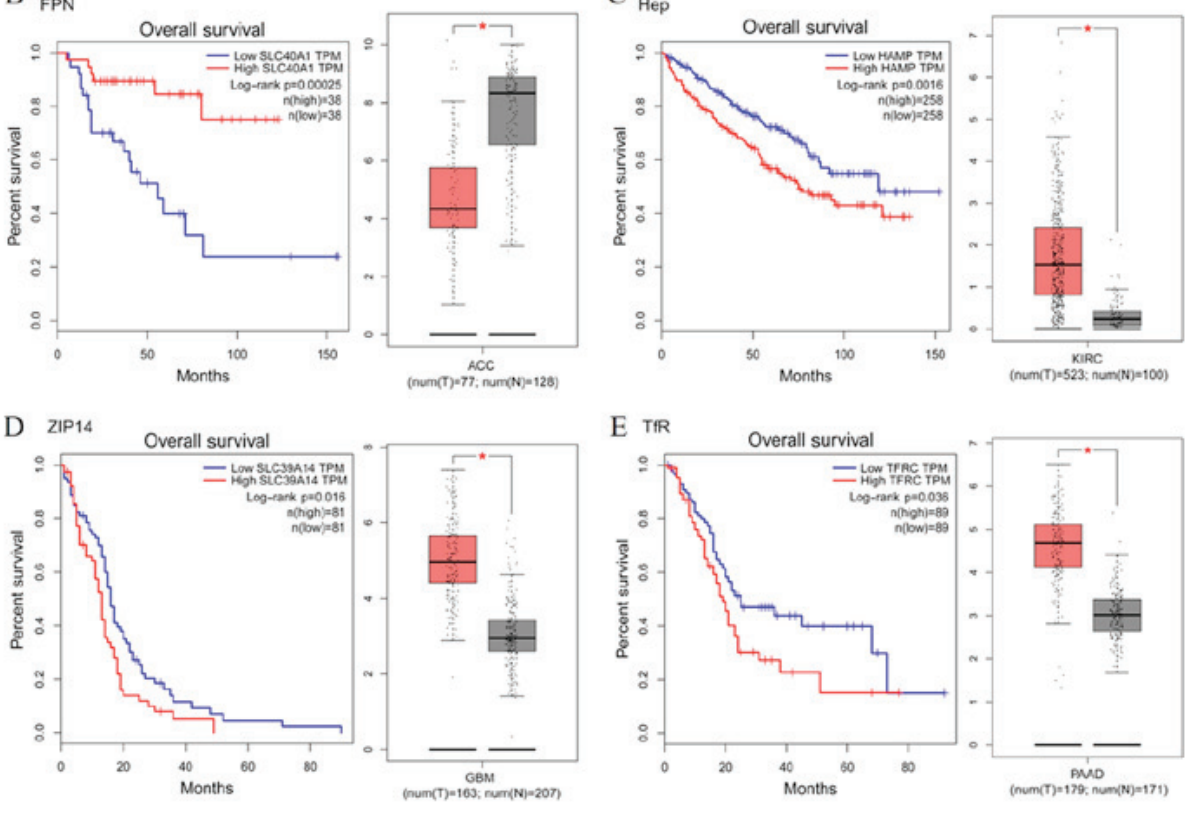

Figure 2. Iron metabolism-associated regulators in cancers. (A) Significantly upregulated (red) and downregulated (blue) expression of iron metabolism genes in 31 tumor samples with potential effects on either improving $(\uparrow)$ or shortening $(\downarrow)$ the OS of patients with cancer compared with controls. The reprehensive OS (left) and altered gene expression (right) of iron regulators for (B) FPN, (C) Hep, (D) ZIP14, (E) TfR. OS data was analyzed using Log-rank test (also known as the Mantel-Cox test). Altered gene expression data were compared with controls using one-way analysis of variance (llog fold changel Cutoff: 1 ; P-value Cutoff: 0.01). ACC, adrenocortical carcinoma; BLCA, bladder urothelial carcinoma; BRCA, breast invasive carcinoma; CESC, cervical squamous cell carcinoma and endocervical adenocarcinoma; CHOL, cholangio carcinoma; COAD, colon adenocarcinoma; DLBC, lymphoid neoplasm diffuse large B-cell lymphoma; ESCA, esophageal carcinoma; GBM, glioblastoma multiforme; HNSC, head and neck squamous cell carcinoma; KICH, kidney chromophobe; KIRC, kidney renal clear cell carcinoma; KIRP, kidney renal papillary cell carcinoma; LAML, acute myeloid leukemia; LGG, brain lower grade glioma; LIHC, liver hepatocellular carcinoma; LUAD, lung adenocarcinoma; LUSC, lung squamous cell carcinoma; OV, ovarian serous cystadenocarcinoma; PAAD, pancreatic adenocarcinoma; PCPG, pheochromocytoma and paraganglioma; PRAD, prostate adenocarcinoma; READ, rectum adenocarcinoma; SARC, sarcoma; SKCM, skin cutaneous melanoma; STAD, stomach adenocarcinoma; TGCT, testicular germ cell tumors; THCA, thyroid carcinoma; THYM, thymoma; UCEC, uterine corpus endometrial carcinoma; UCS, uterine carcinosarcoma; OS, overall survival. FPN, ferroportin; Hep, hepcidin; ZIP14, zinc transporter 14; TfR, transferrin receptor.

gene status and iron overload disease (76). Accumulating evidence suggests that iron excess is closely associated with tumorigenesis in multiple types of human cancer.

Iron metabolism-associated proteins and cancer. To evaluate the contribution of iron metabolism to tumorigenesis, the expression of iron metabolism-associated genes and clinical datasets were retrieved from The Cancer Genome Atlas projects and mined using GEPIA online tools (version 2017; http://gepia.cancer-pku.cn), which processed high-throughput transcriptomic data using standard pipeline (77). As presented in Fig. 2A, for the 31 cancer types, 19 genes involved in iron intake, utilization, efflux or transport were identified, demonstrating either upregulated or downregulated expression in tumor samples compared with normal control samples. To test the hypothesis, the overall survival (OS) data from these patients were analyzed using Log-rank test (also known as the Mantel-Cox test). Altered gene expression data of these patients were compared with controls using one-way analysis of variance ( $\log _{2}$ fold changel Cutoff: 1; P-value Cutoff: 0.01). Considering the patients' OS percentage, it was also observed that specific cancer types exhibit frequent poor or good survival rates, particularly for kidney chromophobe $(\mathrm{KICH})$, kidney renal clear cell carcinoma (KIRC), kidney renal papillary cell carcinoma (KIRP), brain lower grade glioma (LGG) and liver hepatocellular carcinoma (LIHC). The majority of proteins expressed at high levels expression predicted a poor OS for these patients. However, high HCP1, ZIP8, HO-1, Heph and FPN expression demonstrated a good OS in patients with KIRC. Additionally, high Zip8 expression, high Tf expression, and high STEAP3 and ceruloplasmin expression demonstrated a good OS in patients with KIRP, LGG and LIHC, respectively. The survival rates associated with these cancers may be partially due to interrupted iron metabolism in liver and kidney tissues. As presented in Fig. 2B-E, in patients with adrenocortical carcinoma, low FPN expression demonstrated a lower survival rate (Fig. 2B), whereas, high Hep expression predicted a poor OS in patients with KIRC (Fig. 2C). In addition, the high expression of ZIP14 in patients with glioblastoma multiforme or TfR expression in patients with pancreatic adenocarcinoma predicted a poor OS (Fig. 2D and E). Notably, FPN had been demonstrated to transport iron between the inside and outside of the cell, whereas, Hep stops the transit (49). ZIP14 and TfR transfer iron from outside to inside of the cell, which increases the intracellular iron concentration. Supporting the hypothesis that iron-excess contributes to tumorigenesis $(29,60)$.

Colorectal cancer. Colorectal cancer is the third most common cancer in men and second in women worldwide (78). With the exception of hereditary factors, lifestyle factors, including 
physical activity, obesity, smoking and alcohol consumption are closely associated with colorectal cancer (79). The correlation between excess iron and colorectal cancer risk has been examined in numerous previous studies (80-82), and iron overload associated with the H63D mutation and C282Y in HFE may increase the risk for developing colorectal cancer (83-85).

Preoperative anemia is a common phenomenon in patients with colorectal cancer and iron supplementation is the most common therapy (86). However, an analysis of previous studies investigating ingested iron as treatment of anemia identified it as potentially detrimental and hazardous for human colorectal cancer risk (87-89). Recent studies demonstrated that compared with oral iron, intravenous iron therapy is more effective in anemic patients with colorectal cancer with higher Tf and lower ferritin levels $(90,91)$.

Livercancer.Livercanceris one of the mostcommon malignancies in numerous countries worldwide and hepatocellular carcinoma is the most frequent type of global cancer mortality rates (92). A number of factors, including hepatitis $\mathrm{B}$ virus, hepatitis $\mathrm{C}$ virus, alcohol, tobacco, aflatoxin and chronic inflammation are associated with hepatic carcinogenesis (93). Iron overload is a significant risk for hepatocellular carcinoma as the liver is the main organ for iron storage.

Excessive iron accumulation may cause hepatocellular injury. Oversaturated ferritin subunits result in ionic iron releasing into hepatocyte cytoplasm when iron is overloaded (74). If iron stores are excessively overloaded in the liver, the lobules may develop fibrosis. Hereditary haemochromatosis $(\mathrm{HH})$, an inherited iron metabolism disorder, and excess dietary iron are associated with hepatic iron overload. $\mathrm{HH}$ induces hepatic fibrosis and cirrhosis when treatment is not timely and appropriate (94). Patients with $\mathrm{HH}$ possess C282Y mutations on HFE (95). C282Y homozygosity has been correlated with an increased risk of hepatocellular cancer in men (85).

Breast cancer. Breast cancer is the most commonly diagnosed cancer in women, and the number of cases of breast cancer is still increasing (96). It was identified that the development of breast cancer is associated with protein tyrosine phosphorylation (97). Tyrosine phosphorylation is regulated by a careful balance of activity of tyrosine kinases and tyrosine phosphatases, which may activate or inactivate oncogenic pathways in human breast cancer cells (98). Iron chelator aurintricarboxylic acid may inhibit tyrosine phosphatases (99).

A number of genes serve important roles in breast cancer progression through increased iron content in cells. Histone-lysine N-methyltransferase EHMT2 regulates breast cancer growth by modulating iron homeostasis through the repression of ferroxidase hephaestin (100). Dcytb is an important predictor of outcome and is associated with the response to therapy in patients with breast cancer (101).

A mammogram is a test performed to check whether women have breast cancer using X-rays, which subjects the body to radiation. At present, with advances in technology, iron imaging may identify macrophage hemosiderin deposits in metastatic breast cancer (8). Recently, superparamagnetic iron oxide based nanoprobes as multifunctional theranostic agents were applied to breast cancer imaging and therapy (102).
Lung cancer. Lung cancer is the most common leading cause of mortality in cancer during the past several decades (103). There are two types of lung cancer: Non-small cell lung cancer (NSCLC) and small cell lung cancer. Accumulating evidence suggests that iron overload is associated with lung cancer (104). WNT, MYC and hypoxia-inducible factor signaling pathways may be activated by iron $(105,106)$. Subtoxic concentrations of iron induce cellular hydroxyl radicals, affecting cancer stem cell-like subpopulations of human NSCLC cells, which is important for aggressive cancer behaviors and metastasis via transcription factor SOX9 upregulation (107).

Air pollution, particularly particulate matter(PM), increases the risk of respiratory morbidity and mortality, and even lung cancer (108). In PM, iron components have anti-apoptotic effects, which activate nuclear factor erythroid 2-related factor 2-dependent antioxidant processes (109). This previous study provided insight for the development of lung cancer caused by PM pollution; it was hypothesized that a nearby iron foundry may influence the physical condition of local residents. Another study demonstrated that men (aged $<75$ years), but not women, residing within $800 \mathrm{~m}$ of the iron foundry coke oven had a high lung cancer risk (110).

Other cancers. In multiple myeloma, iron metabolism remains unclear. Serum ferritin may serve as a negative prognostic indicator $(111,112)$. Decreased FPN leads to an intracellular iron overload and promotes myeloma cell growth (113). In gastric cancer, iron chelators induce gastric cancer cell apoptosis, involving endoplasmic reticulum stress formed by reactive oxygen species (ROS) and c-Jun N-terminal kinase activation (114).

\section{Mechanisms of iron-mediated proliferation of tumor cells}

Cancer cells have a strong ability to proliferate and metastasize, requiring higher levels of environmental nutrients compared with their healthy counterparts (115). As proliferation is closely associated with the vast biosynthesis of nucleic acids and proteins, the acquisition of energy is particularly vital. Mitochondria are essential organelles for cells, which generate energy and contain diverse enzymes involved in the synthesis (116). Iron is a crucial element of these enzymes and has an important function in the synthesis of these enzymes (117) (Fig. 3).

Mitochondria are one of the principal ancient endomembrane systems and have a circular genome of $\sim 16 \mathrm{~kb}$. The numbers of mitochondria are associated with the vitality of cell types in different tissues (118). Recently, the association between mitochondria and iron was identified. Apart from classic pathways, including $\beta$-oxidation of fatty acids and the tricarboxylic acid cycle, mitochondria are the principal organelles for the metabolism of iron (119). There are three metabolic pathways of mitochondrial iron: Iron-sulfur cluster biogenesis, heme synthesis and iron storage (120). Macrophages store large amounts of iron and serve an important role in tumor progression.

Iron-sulfur cluster. Iron-sulfur cluster biogenesis and mitochondrial iron transport are complex, and includes 16 genes, including SFXN1 and SFXN5 (121). There are 
numerous biological processes that require $\mathrm{Fe}-\mathrm{S}$ proteins including the mitochondrial respiratory chain, DNA replication and repair, and RNA modification (122). As a source of energy, the mitochondrial respiratory chain depends on specific Fe-S cluster-containing enzymes, including NADH-ubiquinone oxidoreductase [additionally termed Complex I (CI)], Rieske iron-sulfur protein (RISP) and subunits of succinate dehydrogenase (SDH, additionally termed succinate-coenzyme $\mathrm{Q}$ reductase or respiratory Complex II) (123). A high concentration of iron and these enzymes promote cellular growth significantly in tumors.

$\mathrm{CI}$ is one of largest membrane-bound enzymes in the cell and is the largest complex of the mitochondrial respiratory chain. The primary function of CI is ATP production, which drives protons across the inner membrane by reducing the potential of NADH. In total, CI is responsible for $40 \%$ of ATP synthesis. There are three subcomplexes of CI: An iron sulfur protein fraction, a flavoprotein fraction and a hydrophobic fraction. The electron transfer centers of CI are associated with redox reactions, which includes eight iron-sulfur clusters, a flavin mononucleotide and ubiquinone (124). CI is indispensable in healthy cells. However, in cancer cells, CI serves an important role in proliferation (125). Small molecular inhibitors serving through CI have been identified as anticancer agents. For example, rotenoids, polyphenols AG311, metformin, BAY 87-2243, fenofibrate, canagliflozin and kalkitoxin offer potential anticancer treatment $(126,127)$.

RISP is an essential subunit of mitochondrial complex III. The progression of the electron transfer reaction requires RISP to dock to the quinol oxidation site; the electron transfer reaction serves a crucial role in the synthesis of ATP (128). A previous study demonstrated that knocking down RISP of mitochondrial complex III in human cancer cells decreased their invasive potential (129). Atovaquone, as a oxidative phosphorylation inhibitor, has been observed to target mitochondrial complex III to eliminate cancer stem cells (130).

SDH is composed of four subunits: A flavoprotein (SDHA), an iron-sulfur protein (SDHB), a cytochrome b560 subunit (SDHC) and cytochrome b small subunit (SDHD). There are three iron-sulfur clusters of SDHB: [2Fe-2S], [4Fe-4S] and [3Fe-4S]. SDH is a key respiratory enzyme complex in the citric acid cycle that converts succinate to fumarate and is also involved in the mitochondrial electron transport chain (131). SDH transfers electrons from the [Fe-S] clusters to ubiquinone (132). SDH has been proposed as a target for cancer therapy. As an inhibitor of SDH, lonidamine provides novel approaches for the treatment of cancer (133). Vitamin E analogues, 3-Bromopyruvate, Malonate, 3-nitropropionic acid, Thenoyltrifluoroacetone and Troglitazone were identified as anticancer agents targeting SDH (134).

Macrophages, iron and tumor cells. The traditional role of macrophages for tumor clearance has been challenged, as it was demonstrated that macrophages have pro-tumor properties. Over the course of cancer progression, tumor cells secrete various mediators to construct their own niche in order to adapt to the surrounding environment (135). It was even observed that tumor-infiltrating macrophages helped tumor cells. Tumor-associated macrophages are principal suppliers of cytokines, proteases and growth factors, such as cysteine cathepsin proteases, which enhance tumor progression and the therapeutic resistance of different cancer types $(136,137)$. For example, in hepatocellular carcinoma and gastric cancer, tumor-associated macrophages promote tumor growth and invasiveness via $\mathrm{C}$ - $\mathrm{C}$ motif chemokine 22-induced epithelial-mesenchymal transition and the activated nuclear factor- $\kappa \mathrm{B}$ signaling pathway $(138,139)$. Furthermore, growing cancer cells demand plenty of iron. Therefore, how tumor cells obtain iron from their microenvironment requires further study.

For the tumor itself, iron may be increased by upregulated expression of iron import and storage proteins, including TfR and ferritin, and downregulated expression of iron export proteins, including FPN (140). In the tumor microenvironment, macrophages secrete lipocalin2 (LCN2), which increases tumor intracellular iron concentration $(141,142)$. LCN2 is a member of the lipocalin superfamily and functions as a carrier protein whose structural feature is a $\beta$-barrel (143). LCN2 is able to bind to iron-loaded siderophores. As a result, tumor-infiltrating macrophages release unlimited iron for tumor cells. A previous study observed that iron in super paramagnetic iron-oxide nanoparticles may target tumor-associated macrophages, which may be used for cancer therapy (144).

\section{Ferroptosis: Iron-dependent cancer cell death}

Ferroptosis, as a novel form of iron-dependent programmed cell death characterized by the accumulation of lipid peroxides, is genetically and biochemically different from pyroptosis, apoptosis and necroptosis (145). Ferroptosis may be triggered by erastin, sorafenib and sulfasalazine $(5,146)$. The accumulation of iron, through the Fenton reaction, generates lipid peroxides and ROS, leading to the occurrence of erastin-induced ferroptosis (147). A number of cancer types exhibit sensitivity to ferroptosis inducers, including large B-cell lymphoma, cervical carcinoma, renal cell carcinoma, osteosarcoma, prostate adenocarcinoma, liver cancer, ovarian carcinoma, pancreatic carcinoma and carcinoma of the lungs (148-151). Notably, ferroptosis inhibitors, such as Liproxstatin-1, may reduce ischemia/reperfusion-induced hepatic damage in $\mathrm{Gpx} 4^{-/-}$mice (152). Other molecular mechanisms of ferroptosis have been identified $(153,154)$.

Erastin inhibits the cystine/glutamate antiporter (system $\mathrm{x}_{\mathrm{c}}{ }^{-}$), which imports cystine from the extracellular matrix $(155,156)$. Cysteine is transported into the cell by system $\mathrm{x}_{\mathrm{c}}{ }^{-}$for the synthesis of glutathione (GSH). Catalyzed by glutathione peroxidase 4 (GPX4), GSH is oxidized to glutathione disulfide, and GPX4 inhibits lipid hydroperoxides (lipid ROS) (157,158). Specific lipid ROS are generated from iron involved in the Fenton reaction. In the absence of GXP4, large amounts of lipid ROS accumulate in cells, which leads to ferroptosis (159-161) (Fig. 4).

Intracellular iron may regulate the sensitivity of cells to ferroptosis. Enhanced intracellular iron promotes erastin-induced ferroptosis; conversely, reduced intracellular iron diminishes ROS, thus suppressing ferroptosis (146). Although ROS induction and iron deprivation therapy may be examined as a possible therapeutic intervention in a variety of cancer types $(13,14)$, the optimal therapeutic strategies have yet to be identified. Therefore, novel therapies, termed ferroptosis therapy, have emerged. Fenton-reaction-acceleratable magnetic 


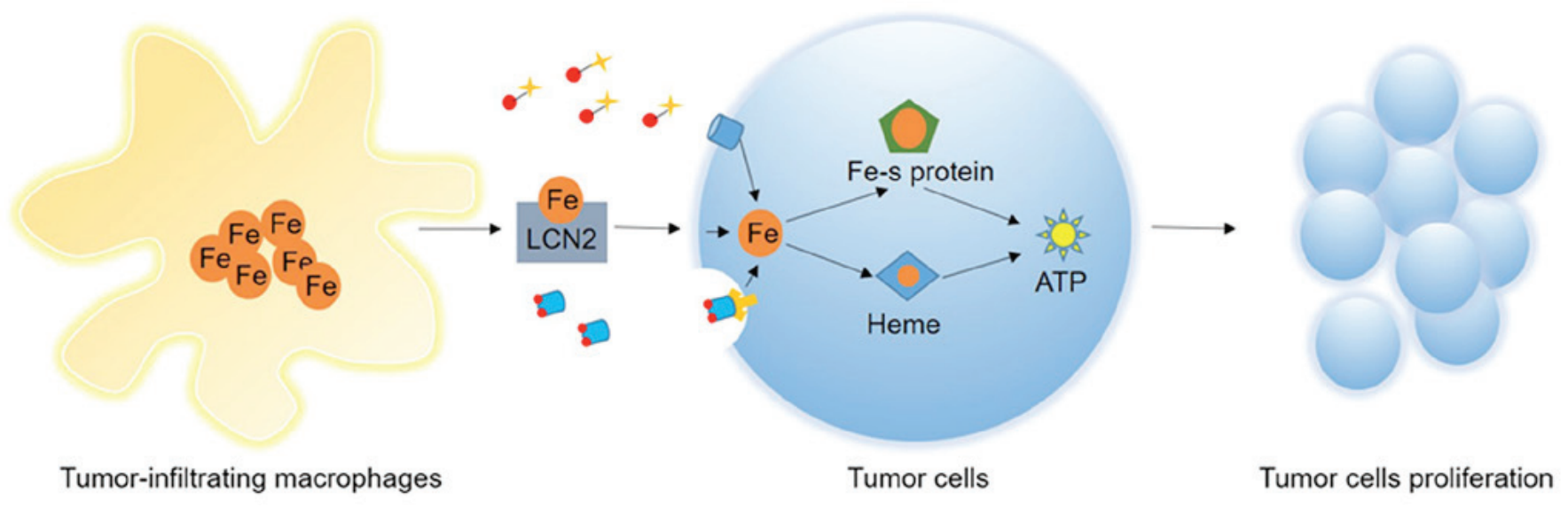

Figure 3. Iron-mediated proliferation mechanisms in tumor cells. LCN2, lipocalin2.

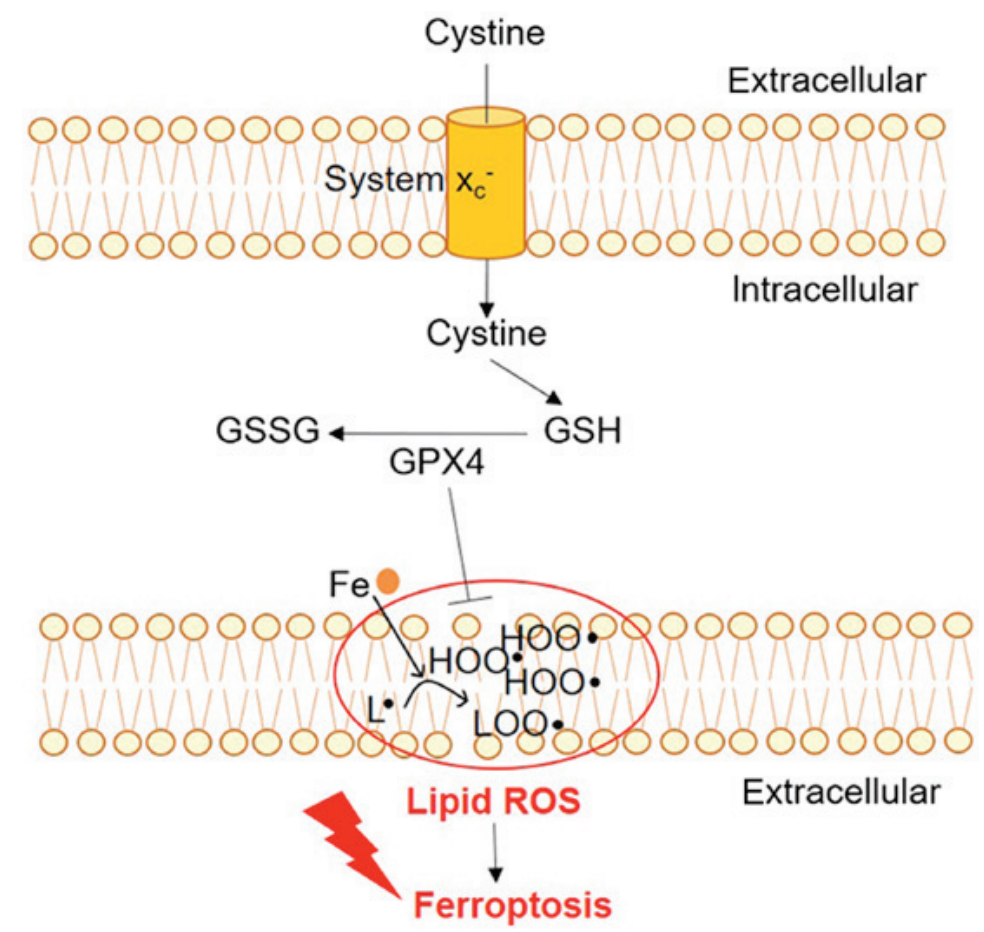

Figure 4. Ferroptosis mechanism. GSH, glutathione; ROS, reactive oxygen species; GPX4, glutathione peroxidase 4; system $\mathrm{x}_{\mathrm{c}}^{-}$, cystine/glutamate antiporter; GSSG, glutathione disulfide.

nanoparticles (FeGd-HN@Pt@LF/RGD2) significantly inhibit tumor growth by delivering Fenton reaction reactants to the tumor site (162). Furthermore, two studies examined tumor suppression mediated by a direct interaction between heme and p53 in iron deprivation $(163,164)$. p53 downregulating metabolic stress-induced ferroptosis in tumors (164) demonstrated that this well-known tumor-suppressor gene is associated with iron metabolism, in addition to cancer cell proliferation and death. In summary, there is great potential for the development of ferroptosis-based effective treatments for iron metabolism-associated diseases and cancer.

\section{Conclusions}

Iron is essential for numerous vital metabolic processes in mammalian systems. The present review focused on the importance of iron regulation, and the association between iron homeostasis and carcinogenic mechanisms, summarizing the progression of research on tumors. Altering iron homeostasis in various cancers may influence patient outcome. Ferroptosis, a unique form of regulated cell death, may serve as a tumor-suppressor for cancer therapy. Taken together, future studies are required to develop novel methods to disturb iron-induced activation, and the resulting signal transduction cascades leading to carcinogenesis and progression.

\section{Acknowledgements}

The authors thank Dr Michael Pisano (Department of Pathology, School of Medicine, University of Iowa, Iowa City, IA, USA) for polishing the language in the current manuscript. 


\section{Funding}

This work was supported by National Natural Science Foundation of China to YY and CG (grant nos. 81670200, 81600177 and 81770220), the 2016 outstanding youth fund of Jiangsu Province to YY (grant no. BK20160048), and the Natural Science Foundation of Jiangsu Province to CG (grant no. BK20161041).

\section{Availability of data and materials}

Not applicable.

\section{Authors' contributions}

$\mathrm{YY}, \mathrm{CG}$ and $\mathrm{ZF}$ were involved in the conception of the review. $\mathrm{CG}$ and $\mathrm{YC}$ were involved in the writing of the article. All authors have read and approved the final manuscript.

\section{Ethics approval and consent to participate}

Not applicable.

\section{Patient consent for publication}

Not applicable.

\section{Competing interests}

The authors declare that they have no competing interests.

\section{References}

1. Kerins MJ and Ooi A: The roles of NRF2 in modulating cellular iron homeostasis. Antioxid Redox Signal 29: 1756-1773, 2018.

2. Andrews NC: Forging a field: The golden age of iron biology. Blood 112: 219-230, 2008.

3. Dielschneider RF, Henson ES and Gibson SB: Lysosomes as oxidative targets for cancer therapy. Oxid Med Cell Longev 2017: 3749157, 2017

4. Ali MK, Kim RY, Karim R, Mayall JR, Martin KL, Shahandeh A, Abbasian F, Starkey MR, Loustaud-Ratti V, Johnstone D, et al: Role of iron in the pathogenesis of respiratory disease. Int J Biochem Cell Biol 88: 181-195, 2017.

5. Manz DH, Blanchette NL, Paul BT, Torti FM and Torti SV: Iron and cancer: Recent insights. Ann NY Acad Sci 1368: 149-161, 2016.

6. Fonseca-Nunes A, Jakszyn P and Agudo A: Iron and cancer risk - a systematic review and meta-analysis of the epidemiological evidence. Cancer Epidemiol Biomarkers Prev 23: 12-31, 2014.

7. Torti SV and Torti FM: Iron and cancer: More ore to be mined. Nat Rev Cancer 13: 342-355, 2013.

8. Leftin A, Ben-Chetrit N, Klemm F, Joyce JA and Koutcher JA: Iron imaging reveals tumor and metastasis macrophage hemosiderin deposits in breast cancer. PLoS One 12: e0184765, 2017.

9. Rouault TA and Maio N: Biogenesis and functions of mammalian iron-sulfur proteins in the regulation of iron homeostasis and pivotal metabolic pathways. J Biol Chem 292: 12744-12753, 2017

10. Fuss JO, Tsai CL, Ishida JP and Tainer JA: Emerging critical roles of $\mathrm{Fe}-\mathrm{S}$ clusters in DNA replication and repair. Biochim Biophys Acta 1853: 1253-1271, 2015.

11. Imlay JA and Linn S: DNA damage and oxygen radical toxicity. Science 240: 1302-1309, 1988

12. Brandt KE, Falls KC, Schoenfeld JD, Rodman SN, Gu Z, Zhan F, Cullen JJ, Wagner BA, Buettner GR, Allen BG, et al: Augmentation of intracellular iron using iron sucrose enhances the toxicity of pharmacological ascorbate in colon cancer cells. Redox Biol 14: 82-87, 2018.
13. Callens C, Coulon S, Naudin J, Radford-Weiss I, Boissel N, Raffoux E, Wang PH, Agarwal S, Tamouza H, Paubelle E, et al: Targeting iron homeostasis induces cellular differentiation and synergizes with differentiating agents in acute myeloid leukemia. J Exp Med 207: 731-750, 2010.

14. Heath JL, Weiss JM, Lavau CP and Wechsler DS: Iron deprivation in cancer - potential therapeutic implications. Nutrients 5: 2836-2859, 2013

15. González A, Gálvez N, Martín J, Reyes F, Pérez-Victoria I and Dominguez-Vera JM: Identification of the key excreted molecule by Lactobacillus fermentum related to host iron absorption. Food Chem 228: 374-380, 2017.

16. Staroń R, Lipiński P, Lenartowicz M, Bednarz A, Gajowiak A Smuda E, Krzeptowski W, Pieszka M, Korolonek T, Hamza I, et al: Dietary hemoglobin rescues young piglets from severe iron deficiency anemia: Duodenal expression profile of genes involved in heme iron absorption. PLoS One 12: e0181117, 2017.

17. Li Y, Jiang H and Huang G: Protein hydrolysates as promoters of non-haem iron absorption. Nutrients 9: 9, 2017.

18. Martínez-Torres $\mathrm{C}$ and Layrisse M: Iron absorption from veal muscle. Am J Clin Nutr 24: 531-540, 1971.

19. Ascenzi P, Leboffe L and Polticelli F: Cyanide binding to human plasma heme-hemopexin: A comparative study. Biochem Biophys Res Commun 428: 239-244, 2012.

20. Colins A, Gerdtzen ZP, Nuñez MT and Salgado JC: Mathematical modeling of intestinal iron absorption using genetic programming. PLoS One 12: e0169601, 2017.

21. Donovan A, Lima CA, Pinkus JL, Pinkus GS, Zon LI, Robine S and Andrews NC: The iron exporter ferroportin/Slc40a1 is essential for iron homeostasis. Cell Metab 1: 191-200, 2005.

22. Sokolov AV, Voynova IV, Kostevich VA, Vlasenko AY, Zakharova ET and Vasilyev VB: Comparison of interaction between ceruloplasmin and lactoferrin/transferrin: To bind or not to bind. Biochemistry (Mosc) 82: 1073-1078, 2017.

23. Nemeth E, Tuttle MS, Powelson J, Vaughn MB, Donovan A, Ward DM, Ganz T and Kaplan J: Hepcidin regulates cellular iron efflux by binding to ferroportin and inducing its internalization. Science 306: 2090-2093, 2004

24. Lane DJ, Bae DH, Merlot AM, Sahni S and Richardson DR: Duodenal cytochrome b (DCYTB) in iron metabolism: An update on function and regulation. Nutrients 7: 2274-2296, 2015.

25. Skjørringe T, Burkhart A, Johnsen KB and Moos T: Divalent metal transporter 1 (DMT1) in the brain: Implications for a role in iron transport at the blood-brain barrier, and neuronal and glial pathology. Front Mol Neurosci 8: 19, 2015.

26. Harrison PM and Arosio P: The ferritins: Molecular properties, iron storage function and cellular regulation. Biochim Biophys Acta 1275: 161-203, 1996.

27. McKie AT and Barlow DJ: The SLC40 basolateral iron transporter family (IREG1/ferroportin/MTP1). Pflugers Arch 447: 801-806, 2004

28. Park CH, Valore EV, Waring AJ and Ganz T: Hepcidin, a urinary antimicrobial peptide synthesized in the liver. J Biol Chem 276: 7806-7810, 2001

29. Liuzzi JP, Aydemir F, Nam H, Knutson MD and Cousins RJ: Zip14 (Slc39a14) mediates non-transferrin-bound iron uptake into cells. Proc Natl Acad Sci USA 103: 13612-13617, 2006.

30. Lin W, Vann DR, Doulias P-T, Wang T, Landesberg G, Li X, Ricciotti E, Scalia R, He M, Hand NJ, et al: Hepatic metal ion transporter ZIP8 regulates manganese homeostasis and manganese-dependent enzyme activity. J Clin Invest 127: 2407-2417, 2017.

31. Mwanjewe J and Grover AK: Role of transient receptor potential canonical 6 (TRPC6) in non-transferrin-bound iron uptake in neuronal phenotype PC12 cells. Biochem J 378: 975-982, 2004.

32. Knutson MD: Non-transferrin-bound iron transporters. Free Radic Biol Med 133: 101-111, 2019.

33. Yoshizaki T, Uematsu M, Obata JE, Nakamura T, Fujioka D, Watanabe K, Nakamura K and Kugiyama K: Angiotensin II receptor blockers suppress the release of stromal cell-derived factor-1alpha from infarcted myocardium in patients with acute myocardial infarction. J Cardiol 71: 367-374, 2018.

34. Recuenco MC, Rahman MM, Takeuchi F, Kobayashi K and Tsubaki M: Electron transfer reactions of candidate tumor suppressor 101F6 protein, a cytochrome b561 homologue, with ascorbate and monodehydroascorbate radical. Biochemistry 52 : 3660-3668, 2013.

35. Lane DJ and Lawen A: Ascorbate and plasma membrane electron transport - enzymes vs efflux. Free Radic Biol Med 47: 485-495, 2009. 
36. Anderson SA, Nizzi CP, Chang YI, Deck KM, Schmidt PJ, Galy B, Damnernsawad A, Broman AT, Kendziorski C, Hentze MW, et al: The IRP1-HIF-2 $\alpha$ axis coordinates iron and oxygen sensing with erythropoiesis and iron absorption. Cell Metab 17: 282-290, 2013.

37. Coates TD: Physiology and pathophysiology of iron in hemoglobin-associated diseases. Free Radic Biol Med 72: 23-40, 2014.

38. Gunshin H, Allerson CR, Polycarpou-Schwarz M, Rofts A, Rogers JT, Kishi F, Hentze MW, Rouault TA, Andrews NC and Hediger MA: Iron-dependent regulation of the divalent metal ion transporter. FEBS Lett 509: 309-316, 2001.

39. Anderson CP, Shen M, Eisenstein RS and Leibold EA Mammalian iron metabolism and its control by iron regulatory proteins. Biochim Biophys Acta 1823: 1468-1483, 2012.

40. Ford GC, Harrison PM, Rice DW, Smith JM, Treffry A, White JL and Yariv J: Ferritin: Design and formation of an iron-storage molecule. Philos Trans R Soc Lond B Biol Sci 304: 551-565, 1984.

41. Carmona U, Li L, Zhang L and Knez M: Ferritin light-chain subunits: Key elements for the electron transfer across the protein cage. Chem Commun (Camb) 50: 15358-15361, 2014.

42. Kukulj S, Jaganjac M, Boranic M, Krizanac S, Santic Z and Poljak-Blazi M: Altered iron metabolism, inflammation, transferrin receptors, and ferritin expression in non-small-cell lung cancer. Med Oncol 27: 268-277, 2010.

43. Ganz T and Nemeth E: Iron metabolism: Interactions with normal and disordered erythropoiesis. Cold Spring Harb Perspect Med 2: a011668, 2012.

44. Cianetti L, Gabbianelli $M$ and Sposi NM: Ferroportin and erythroid cells: an update. Adv Hematol 2010: 404173, 2010.

45. Wallace DF, McDonald CJ, Ostini L, Iser D, Tuckfield A and Subramaniam VN: The dynamics of hepcidin-ferroportin internalization and consequences of a novel ferroportin disease mutation. Am J Hematol 92: 1052-1061, 2017.

46. El Hage Chahine JM, Hémadi M and Ha-Duong NT: Uptake and release of metal ions by transferrin and interaction with receptor 1. Biochim Biophys Acta 1820: 334-347, 2012.

47. Frazer DM and Anderson GJ: The regulation of iron transport Biofactors 40: 206-214, 2014

48. Addo L, Ikuta K, Tanaka H, Toki Y, Hatayama M, Yamamoto M, Ito S, Shindo M, Sasaki Y, Shimonaka Y, et al: The three isoforms of hepcidin in human serum and their processing determined by liquid chromatography-tandem mass spectrometry (LC-tandem MS). Int J Hematol 103: 34-43, 2016.

49. Qiao B, Sugianto P, Fung E, Del-Castillo-Rueda A Moran-Jimenez MJ, Ganz T and Nemeth E: Hepcidin-induced endocytosis of ferroportin is dependent on ferroportin ubiquitination. Cell Metab 15: 918-924, 2012

50. Ramos E, Kautz L, Rodriguez R, Hansen M, Gabayan V, Ginzburg Y, Roth MP, Nemeth E and Ganz T: Evidence for distinct pathways of hepcidin regulation by acute and chronic iron loading in mice. Hepatology 53: 1333-1341, 2011.

51. Coffey R and Ganz T: Iron homeostasis: An anthropocentric perspective. J Biol Chem 292: 12727-12734, 2017.

52. Pietrangelo A, Dierssen U, Valli L, Garuti C, Rump A, Corradini E, Ernst M, Klein C and Trautwein C: STAT3 is required for IL-6-gp130-dependent activation of hepcidin in vivo. Gastroenterology 132: 294-300, 2007.

53. Palis J: Primitive and definitive erythropoiesis in mammals. Front Physiol 5: 3, 2014.

54. Papanikolaou G and Pantopoulos K: Systemic iron homeostasis and erythropoiesis. IUBMB Life 69: 399-413, 2017.

55. Shaw GC, Cope JJ, Li L, Corson K, Hersey C, Ackermann GE, Gwynn B, Lambert AJ, Wingert RA, Traver D, et al: Mitoferrin is essential for erythroid iron assimilation. Nature 440: 96-100, 2006.

56. Beaumont $\mathrm{C}$ and Canonne-Hergaux F: Erythrophagocytosis and recycling of heme iron in normal and pathological conditions; regulation by hepcidin. Transfus Clin Biol 12: 123-130, 2005.

57. Theurl I, Hilgendorf I, Nairz M, Tymoszuk P, Haschka D, Asshoff M, He S, Gerhardt LM, Holderried TA, Seifert M, et al: On-demand erythrocyte disposal and iron recycling requires transient macrophages in the liver. Nat Med 22: 945-951, 2016.

58. Soe-Lin S, Apte SS, Mikhael MR, Kayembe LK, Nie G and Ponka P: Both Nramp1 and DMT1 are necessary for efficient macrophage iron recycling. Exp Hematol 38: 609-617, 2010.

59. Poss KD and Tonegawa S: Heme oxygenase 1 is required for mammalian iron reutilization. Proc Natl Acad Sci USA 94: 10919-10924, 1997.

60. Qian ZM and Tang PL: Mechanisms of iron uptake by mammalian cells. Biochim Biophys Acta 1269: 205-214, 1995.
61. Morgan EH: Chelator-mediated iron efflux from reticulocytes. Biochim Biophys Acta 733: 39-50, 1983.

62. Wang CY, Jenkitkasemwong S, Duarte S, Sparkman BK Shawki A, Mackenzie B and Knutson MD: ZIP8 is an iron and zinc transporter whose cell-surface expression is up-regulated by cellular iron loading. J Biol Chem 287: 34032-34043, 2012.

63. Pinilla-Tenas JJ, Sparkman BK, Shawki A, Illing AC, Mitchell CJ, Zhao N, Liuzzi JP, Cousins RJ, Knutson MD and Mackenzie B: Zip14 is a complex broad-scope metal-ion transporter whose functional properties support roles in the cellular uptake of zinc and nontransferrin-bound iron. Am J Physiol Cell Physiol 301: C862-C871, 2011.

64. Tsushima RG, Wickenden AD, Bouchard RA, Oudit GY, Liu PP and Backx PH: Modulation of iron uptake in heart by L-type $\mathrm{Ca}^{2+}$ channel modifiers: Possible implications in iron overload. Circ Res 84: 1302-1309, 1999.

65. Brittenham GM, Andersson M, Egli I, Foman JT, Zeder C, Westerman ME and Hurrell RF: Circulating non-transferrin-bound iron after oral administration of supplemental and fortification doses of iron to healthy women: A randomized study. Am J Clin Nutr 100: 813-820, 2014.

66. Pinto JP, Arezes J, Dias V, Oliveira S, Vieira I, Costa M, Vos M, Carlsson A, Rikers Y, Rangel M, et al: Physiological implications of NTBI uptake by T lymphocytes. Front Pharmacol 5: $24,2014$.

67. Ramey G, Deschemin JC, Durel B, Canonne-Hergaux F, Nicolas $G$ and Vaulont S: Hepcidin targets ferroportin for degradation in hepatocytes. Haematologica 95: 501-504, 2010.

68. Iancu TC, Ward RJ and Peters TJ: Ultrastructural changes in the pancreas of carbonyl iron-fed rats. J Pediatr Gastroenterol Nutr 10: 95-101, 1990.

69. Paragas N, Qiu A, Hollmen M, Nickolas TL, Devarajan P and Barasch J: NGAL-Siderocalin in kidney disease. Biochim Biophys Acta 1823: 1451-1458, 2012

70. Martines AM, Masereeuw R, Tjalsma H, Hoenderop JG, Wetzels JF and Swinkels DW: Iron metabolism in the pathogenesis of iron-induced kidney injury. Nat Rev Nephrol 9: 385-398, 2013.

71. Lakhal-Littleton S, Wolna M, Carr CA, Miller JJ, Christian HC, Ball V, Santos A, Diaz R, Biggs D, Stillion R, et al: Cardiac ferroportin regulates cellular iron homeostasis and is important for cardiac function. Proc Natl Acad Sci USA 112: 3164-3169, 2015.

72. Richmond HG: Induction of sarcoma in the rat by iron-dextran complex. BMJ 1: 947-949, 1959.

73. Xue $X$ and Shah YM: Intestinal iron homeostasis and colon tumorigenesis. Nutrients 5: 2333-2351, 2013.

74. Kew MC: Hepatic iron overload and hepatocellular carcinoma. Liver Cancer 3: 31-40, 2014.

75. Stevens RG, Cologne JB, Nakachi K, Grant EJ and Neriishi K: Body iron stores and breast cancer risk in female atomic bomb survivors. Cancer Sci 102: 2236-2240, 2011.

76. Huang $X$ : Iron overload and its association with cancer risk in humans: Evidence for iron as a carcinogenic metal. Mutat Res 533: 153-171, 2003

77. Tang Z, Li C, Kang B, Gao G, Li C and Zhang Z: GEPIA: A web server for cancer and normal gene expression profiling and interactive analyses. Nucleic Acids Res 45: W98-W102, 2017.

78. Ferlay J, Soerjomataram I, Dikshit R, Eser S, Mathers C, Rebelo M, Parkin DM, Forman D and Bray F: Cancer incidence and mortality worldwide: Sources, methods and major patterns in GLOBOCAN 2012. Int J Cancer 136: E359-E386, 2015.

79. Haggar FA and Boushey RP: Colorectal cancer epidemiology: Incidence, mortality, survival, and risk factors. Clin Colon Rectal Surg 22: 191-197, 2009.

80. Chua ACG, Klopcic B, Lawrance IC, Olynyk JK and Trinder D: Iron: An emerging factor in colorectal carcinogenesis. World J Gastroenterol 16: 663-672, 2010.

81. Kato I, Dnistrian AM, Schwartz M, Toniolo P, Koenig K, Shore RE, Zeleniuch-Jacquotte A, Akhmedkhanov A and Riboli E: Iron intake, body iron stores and colorectal cancer risk in women: A nested case-control study. Int J Cancer 80: 693-698, 1999.

82. Wilson MJ, Dekker JWT, Harlaar JJ, Jeekel J, Schipperus M and Zwaginga JJ: The role of preoperative iron deficiency in colorectal cancer patients: Prevalence and treatment. Int J Colorectal Dis 32: 1617-1624, 2017.

83. de Juan D, Reta A, Castiella A, Pozueta J, Prada A and Cuadrado E: HFE gene mutations analysis in Basque hereditary haemochromatosis patients and controls. Eur J Hum Genet 9: 961-964, 2001 
84. Castiella A, Múgica F, Zapata E, Zubiaurre L, Iribarren A de Juan MD, Alzate L, Gil I, Urdapilleta G, Otazua P, et al Gender and plasma iron biomarkers, but not HFE gene mutations, increase the risk of colorectal cancer and polyps. Tumour Biol 36: 6959-6963, 2015.

85. Asberg A, Thorstensen K, Irgens WO, Romundstad PR and Hveem K: Cancer risk in HFE C282Y homozygotes: Results from the HUNT 2 study. Scand J Gastroenterol 48: 189-195, 2013

86. Ludwig H, Müldür E, Endler G and Hübl W: Prevalence of iron deficiency across different tumors and its association with poor performance status, disease status and anemia. Ann Oncol 24 1886-1892, 2013.

87. Nelson RL: Dietary iron and colorectal cancer risk. Free Radic Biol Med 12: 161-168, 1992

88. Wilson MJ, Harlaar JJ, Jeekel J, Schipperus M and Zwaginga JJ: Iron therapy as treatment of anemia: A potentially detrimental and hazardous strategy in colorectal cancer patients. Med Hypotheses 110: 110-113, 2018.

89. Joosten E, Meeuwissen J, Vandewinckele H and Hiele M: Iron status and colorectal cancer in symptomatic elderly patients. Am J Med 121: 1072-1077, 2008.

90. Wilson MJ, Dekker JW, Bruns E, Borstlap W, Jeekel J, Zwaginga JJ and Schipperus M: Short-term effect of preoperative intravenous iron therapy in colorectal cancer patient with anemia: Results of a cohort study. Transfusion 58: 795-803, 2018.

91.Laso-Morales M, Jericó C, Gómez-Ramírez S, Castellví J, Viso L, Roig-Martínez I, Pontes C and Muñoz M: Preoperative management of colorectal cancer-induced iron deficiency anemia in clinical practice: Data from a large observational cohort. Transfusion 57: 3040-3048, 2017.

92. Baecker A, Liu X, La Vecchia C and Zhang ZF: Worldwide incidence of hepatocellular carcinoma cases attributable to major risk factors. Eur J Cancer Prev 27: 205-212, 2018.

93. Sun B and Karin M: Obesity, inflammation, and liver cancer. J Hepatol 56: 704-713, 2012.

94. Bardou-Jacquet E, Morcet J, Manet G, Lainé F, Perrin M, Jouanolle AM, Guyader D, Moirand R, Viel JF and Deugnier Y: Decreased cardiovascular and extrahepatic cancer-related mortality in treated patients with mild HFE hemochromatosis. J Hepatol 62: 682-689, 2015.

95. Grosse SD, Rogowski WH, Ross LF, Cornel MC, Dondorp WJ and Khoury MJ: Population screening for genetic disorders in the 21st century: Evidence, economics, and ethics. Public Health Genomics 13: 106-115, 2010.

96. Da Costa GG, Gomig TH, Kaviski R, Santos Sousa K, Kukolj C, De Lima RS, De Andrade Urban C, Cavalli IJ and Ribeiro EM: Comparative proteomics of tumor and paired normal breast tissue highlights potential biomarkers in breast cancer. Cance Genomics Proteomics 12: 251-261, 2015.

97. Nunes-Xavier CE, Martín-Pérez J, Elson A and Pulido R: Protein tyrosine phosphatases as novel targets in breast cancer therapy. Biochim Biophys Acta 1836: 211-226, 2013.

98. Tonks NK: Protein tyrosine phosphatases: From genes, to function, to disease. Nat Rev Mol Cell Biol 7: 833-846, 2006.

99. Kuban-Jankowska A, Sahu KK, Gorska-Ponikowska M, Tuszynski JA and Wozniak M: Inhibitory activity of iron chelators ATA and DFO on MCF-7 breast cancer cells and phosphatases PTP1B and SHP2. Anticancer Res 37: 4799-4806, 2017.

100. Wang YF, Zhang J, Su Y, Shen YY, Jiang DX, Hou YY, Geng MY, Ding J and Chen Y: G9a regulates breast cancer growth by modulating iron homeostasis through the repression of ferroxidase hephaestin. Nat Commun 8: 274, 2017

101.Lemler DJ, Lynch ML, Tesfay L, Deng Z, Paul BT, Wang X, Hegde P, Manz DH, Torti SV and Torti FM: DCYTB is a predictor of outcome in breast cancer that functions via iron-independent mechanisms. Breast Cancer Res 19: 25, 2017.

102. Zheng J, Ren W, Chen T, Yinhua J, Li A, Yan K, Wu Y and Wu A Recent advances in superparamagnetic iron oxide based nanoprobes as multifunctional theranostic agents for breast cancer imaging and therapy. Curr Med Chem 25: 3001-3016, 2018

103. Ridge CA, McErlean AM and Ginsberg MS: Epidemiology of lung cancer. Semin Intervent Radiol 30: 93-98, 2013.

104. Wild P, Bourgkard E and Paris C: Lung cancer and exposure to metals: The epidemiological evidence. Methods Mol Biol 472: $139-167,2009$

105. Brookes MJ, Boult J, Roberts K, Cooper BT, Hotchin NA, Matthews G, Iqbal T and Tselepis C: A role for iron in Wnt signalling. Oncogene 27: 966-975, 2008.
106. Wu KJ, Polack A and Dalla-Favera R: Coordinated regulation of iron-controlling genes, $\mathrm{H}$-ferritin and IRP2, by c-MYC. Science 283: 676-679, 1999.

107. Chanvorachote $\mathrm{P}$ and Luanpitpong S: Iron induces cancer stem cells and aggressive phenotypes in human lung cancer cells. Am J Physiol Cell Physiol 310: C728-C739, 2016.

108. Lee BJ, Kim B and Lee K: Air pollution exposure and cardiovascular disease. Toxicol Res 30: 71-75, 2014.

109. Lovera-Leroux M, Crobeddu B, Kassis N, Petit PX, Janel N, Baeza-Squiban A and Andreau K: The iron component of particulate matter is antiapoptotic: A clue to the development of lung cancer after exposure to atmospheric pollutants? Biochimie 118: 195-206, 2015

110. Bidoli E, Barbone F, Collarile P, Valent F, Zanier L, Daris F, Gini A, Birri S and Serraino D: Residence in proximity of an iron foundry and risk of lung cancer in the municipality of trieste, Italy, 1995-2009. Int J Environ Res Public Health 12: 9025-9035, 2015.

111. Song MK, Chung JS, Seol YM, Shin HJ, Choi YJ and Cho GJ: Elevation of serum ferritin is associated with the outcome of patients with newly diagnosed multiple myeloma. Korean Korean J Intern Med 24: 368-373, 2009.

112. Strasser-Weippl K and Ludwig H: Ferritin as prognostic marker in multiple myeloma patients undergoing autologous transplantation. Leuk Lymphoma 55: 2520-2524, 2014.

113. Gu Z, Wang H, Xia J, Yang Y, Jin Z, Xu H, Shi J, De Domenico I, Tricot $\mathrm{G}$ and Zhan F: Decreased ferroportin promotes myeloma cell growth and osteoclast differentiation. Cancer Res 75: 2211-2221, 2015

114. Kim JL, Lee D-H, Na YJ, Kim BR, Jeong YA, Lee SI, Kang S, Joung SY, Lee S-Y, Oh SC, et al: Iron chelator-induced apoptosis via the ER stress pathway in gastric cancer cells. Tumour Biol 37: 9709-9719, 2016

115. Timofeeva OA, Palechor-Ceron N, Li G, Yuan H, Krawczyk E, Zhong X, Liu G, Upadhyay G, Dakic A, Yu S, et al: Conditionally reprogrammed normal and primary tumor prostate epithelial cells: A novel patient-derived cell model for studies of human prostate cancer. Oncotarget 8: 22741-22758, 2017.

116. Wachowius F, Attwater J and Holliger P: Nucleic acids: Function and potential for abiogenesis. Q Rev Biophys 50: e4, 2017.

117. Puig S, Ramos-Alonso L, Romero AM and Martínez-Pastor MT: The elemental role of iron in DNA synthesis and repair. Metallomics 9: 1483-1500, 2017.

118. Friedman JR and Nunnari J: Mitochondrial form and function. Nature 505: 335-343, 2014.

119. Ren JG, Seth P, Ye H, Guo K, Hanai JI, Husain Z and Sukhatme VP: Citrate suppresses tumor growth in multiple models through inhibition of glycolysis, the tricarboxylic acid cycle and the IGF-1R pathway. Sci Rep 7: 4537, 2017.

120. Dutkiewicz R and Nowak M: Molecular chaperones involved in mitochondrial iron-sulfur protein biogenesis. J Biol Inorg Chem 23: 569-579, 2018.

121. Miller LD, Coffman LG, Chou JW, Black MA, Bergh J, D'Agostino R Jr, Torti SV and Torti FM: An iron regulatory gene signature predicts outcome in breast cancer. Cancer Res 71: 6728-6737, 2011.

122. Mettert EL and Kiley PJ: Fe-S proteins that regulate gene expression. Biochim Biophys Acta 1853: 1284-1293, 2015.

123. Zhang L, Reyes A and Wang X: The role of DNA repair in maintaining mitochondrial DNA stability. Adv Exp Med Biol 1038: 85-105, 2017

124. Chen YR and Zweier JL: Cardiac mitochondria and reactive oxygen species generation. Circ Res 114: 524-537, 2014

125. Urra FA, Muñoz F, Lovy A and Cárdenas C: The mitochondrial complex(I)ty of cancer. Front Oncol 7: 118, 2017.

126. Bastian A, Matsuzaki S, Humphries KM, Pharaoh GA, Doshi A, Zaware N, Gangjee A and Ihnat MA: AG311, a small molecule inhibitor of complex I and hypoxia-induced HIF-1 $\alpha$ stabilization. Cancer Lett 388: 149-157, 2017.

127. Bridges HR, Jones AJ, Pollak MN and Hirst J: Effects of metformin and other biguanides on oxidative phosphorylation in mitochondria. Biochem J 462: 475-487, 2014.

128. Esser L, Zhou F, Zhou Y, Xiao Y, Tang WK, Yu CA, Qin Z and $\mathrm{Xia} \mathrm{D}$ : Hydrogen bonding to the substrate is not required for rieskeiron-sulfur protein docking to the quinol oxidation site of complex III. J Biol Chem 291: 25019-25031, 2016.

129. Wang F, Zhang R, Xia T, Hsu E, Cai Y, Gu Z and Hankinson O: Inhibitory effects of nitric oxide on invasion of human cancer cells. Cancer Lett 257: 274-282, 2007. 
130. Fiorillo M,Lamb R, Tanowitz HB, Mutti L, Krstic-Demonacos M, Cappello AR, Martinez-Outschoorn UE, Sotgia F and Lisanti MP: Repurposing atovaquone: Targeting mitochondrial complex III and OXPHOS to eradicate cancer stem cells. Oncotarget 7: 34084-34099, 2016.

131. Oyedotun KS and Lemire BD: The quaternary structure of the Saccharomyces cerevisiae succinate dehydrogenase. Homology modeling, cofactor docking, and molecular dynamics simulation studies. J Biol Chem 279: 9424-9431, 2004.

132. Sun F, Huo X, Zhai Y, Wang A, Xu J, Su D, Bartlam M and Rao Z: Crystal structure of mitochondrial respiratory membrane protein complex II. Cell 121: 1043-1057, 2005

133. Guo L, Shestov AA, Worth AJ, Nath K, Nelson DS, Leeper DB, Glickson JD and Blair IA: Inhibition of mitochondrial complex II by the anticancer agent lonidamine. J Biol Chem 291: 42-57, 2016.

134.Kluckova K, Bezawork-Geleta A, Rohlena J, Dong L and Neuzil J: Mitochondrial complex II, a novel target for anti-cancer agents. Biochim Biophys Acta 1827: 552-564, 2013.

135. Quail DF and Joyce JA: Microenvironmental regulation of tumor progression and metastasis. Nat Med 19: 1423-1437, 2013.

136. Shree T, Olson OC, Elie BT, Kester JC, Garfall AL, Simpson K, Bell-McGuinn KM, Zabor EC, Brogi E and Joyce JA: Macrophages and cathepsin proteases blunt chemotherapeutic response in breast cancer. Genes Dev 25: 2465-2479, 2011.

137. Gocheva V, Wang HW, Gadea BB, Shree T, Hunter KE, Garfall AL, Berman T and Joyce JA: IL-4 induces cathepsin protease activity in tumor-associated macrophages to promote cancer growth and invasion. Genes Dev 24: 241-255, 2010.

138. Yeung OW, Lo CM, Ling CC, Qi X, Geng W, Li CX, Ng KT, Forbes SJ, Guan XY, Poon RT, et al: Alternatively activated (M2) macrophages promote tumour growth and invasiveness in hepatocellular carcinoma. J Hepatol 62: 607-616, 2015.

139. Wu L, Zhang X, Zhang B, Shi H, Yuan X, Sun Y, Pan Z, Qian H and $\mathrm{Xu} \mathrm{W}$ : Exosomes derived from gastric cancer cells activate $\mathrm{NF}-\kappa \mathrm{B}$ pathway in macrophages to promote cancer progression. Tumour Biol 37: 12169-12180, 2016.

140. Torti SV and Torti FM: Cellular iron metabolism in prognosis and therapy of breast cancer. Crit Rev Oncog 18: 435-448, 2013.

141. Duan X, He K, Li J, Cheng M, Song H, Liu J and Liu P: Tumor associated macrophages deliver iron to tumor cells via Lcn2. Int J Physiol Pathophysiol Pharmacol 10: 105-114, 2018.

142. Mertens C, Mora J, Ören B, Grein S, Winslow S, Scholich K, Weigert A, Malmström P, Forsare C, Fernö M, et al: Macrophage-derived lipocalin-2 transports iron in the tumor microenvironment. OncoImmunology 7: e1408751, 2017.

143. Flower DR: The lipocalin protein family: A role in cell regulation. FEBS Lett 354: 7-11, 1994

144.Laskar A, Eilertsen J, Li W and Yuan XM: SPION primes THP1 derived M2 macrophages towards M1-like macrophages. Biochem Biophys Res Commun 441: 737-742, 2013.

145. Fearnhead HO, Vandenabeele P and Vanden Berghe T: How do we fit ferroptosis in the family of regulated cell death? Cell Death Differ 24: 1991-1998, 2017.

146. Dixon SJ, Lemberg KM, Lamprecht MR, Skouta R, Zaitsev EM, Gleason CE, Patel DN, Bauer AJ, Cantley AM, Yang WS, et al: Ferroptosis: An iron-dependent form of nonapoptotic cell death. Cell 149: 1060-1072, 2012.

147. Sheng X, Shan C, Liu J, Yang J, Sun B and Chen D: Theoretical insights into the mechanism of ferroptosis suppression via inactivation of a lipid peroxide radical by liproxstatin- 1 . Phys Chem Chem Phys 19: 13153-13159, 2017.
148. Fanzani A and Poli M: Iron, oxidative damage and ferroptosis in rhabdomyosarcoma. Int J Mol Sci 18: 18, 2017.

149. Alvarez SW, Sviderskiy VO, Terzi EM, Papagiannakopoulos T, Moreira AL, Adams S, Sabatini DM, Birsoy K and Possemato R NFS1 undergoes positive selection in lung tumours and protects cells from ferroptosis. Nature 551: 639-643, 2017.

150. Sun X, Ou Z, Xie M, Kang R, Fan Y, Niu X, Wang H, Cao L and Tang D: HSPB1 as a novel regulator of ferroptotic cancer cell death. Oncogene 34: 5617-5625, 2015.

151. Doll S, Proneth B, Tyurina YY, Panzilius E, Kobayashi S, Ingold I, Irmler M, Beckers J, Aichler M, Walch A, et al: ACSL4 dictates ferroptosis sensitivity by shaping cellular lipid composition. Nat Chem Biol 13: 91-98, 2017.

152. Friedmann Angeli JP, Schneider M, Proneth B, Tyurina YY, Tyurin VA, Hammond VJ, Herbach N, Aichler M, Walch A, Eggenhofer E, et al: Inactivation of the ferroptosis regulator Gpx4 triggers acute renal failure in mice. Nat Cell Biol 16: 1180-1191, 2014

153. Cao JY and Dixon SJ: Mechanisms of ferroptosis. Cell Mol Life Sci 73: 2195-2209, 2016

154. Stockwell BR, Friedmann Angeli JP, Bayir H,Bush AI, Conrad M, Dixon SJ, Fulda S, Gascón S, Hatzios SK, Kagan VE, et al: Ferroptosis: A regulated cell death nexus linking metabolism, redox biology, and disease. Cell 171: 273-285, 2017.

155. Ishii T, Sugita Y and Bannai S: Regulation of glutathione levels in mouse spleen lymphocytes by transport of cysteine. J Cell Physiol 133: 330-336, 1987

156. Lou L, Kang J, Pang H, Li Q, Du X, Wu W, Chen J and Lv J: Sulfur protects Pakchoi (Brassica chinensis L.) seedlings against cadmium stress by regulating ascorbate-glutathione metabolism. Int J Mol Sci 18: 18, 2017.

157.Dolma S, Lessnick SL, Hahn WC and Stockwell BR: Identification of genotype-selective antitumor agents using synthetic lethal chemical screening in engineered human tumor cells. Cancer Cell 3: 285-296, 2003.

158. Seiler A, Schneider M, Förster H, Roth S, Wirth EK, Culmsee C, Plesnila N, Kremmer E, Rådmark O, Wurst W, et al: Glutathione peroxidase 4 senses and translates oxidative stress into 12/15-lipoxygenase dependent- and AIF-mediated cell death. Cell Metab 8: 237-248, 2008.

159. Ursini $\mathrm{F}$ and Bindoli A: The role of selenium peroxidases in the protection against oxidative damage of membranes. Chem Phys Lipids 44: 255-276, 1987

160. Chu FF: The human glutathione peroxidase genes GPX2, GPX3, and GPX4 map to chromosomes 14, 5, and 19, respectively. Cytogenet Cell Genet 66: 96-98, 1994.

161. Yang WS, SriRamaratnam R, Welsch ME, Shimada K, Skouta R, Viswanathan VS, Cheah JH, Clemons PA, Shamji AF, Clish CB, et al: Regulation of ferroptotic cancer cell death by GPX4. Cell 156: 317-331, 2014.

162. Shen Z, Liu T, Li Y, Lau J, Yang Z, Fan W, Zhou Z, Shi C, Ke C, Bregadze VI, et al: Fenton-reaction-acceleratable magnetic nanoparticles for ferroptosis therapy of orthotopic brain tumors. ACS Nano 12: 11355-11365, 2018.

163. Shen J, Sheng X, Chang Z, Wu Q, Wang S, Xuan Z, Li D, Wu Y, Shang Y, Kong X, et al: Iron metabolism regulates p53 signaling through direct heme-p53 interaction and modulation of p53 localization, stability, and function. Cell Rep 7: 180-193, 2014.

164. Tarangelo A, Magtanong L, Bieging-Rolett KT, Li Y, Ye J, Attardi LD and Dixon SJ: p53 suppresses metabolic stress-induced ferroptosis in cancer cells. Cell Rep 22: 569-575, 2018. 